\title{
The Impact of Globalisation on Value-added Wood Products Trade
}

\author{
Michal Dzian ${ }^{1,{ }^{*}, \text { Hubert Paluš }}{ }^{1}$, and Ján Parobek ${ }^{1}$ \\ ${ }^{1}$ Technical University in Zvolen, Faculty of Wood Sciences and Technology, Department of Marketing, \\ Trade and World Forestry, T. G. Masaryka 24, 96053 Zvolen, Slovak Republic
}

\begin{abstract}
.
Research background: The development of the Slovak economy depends on the demand in foreign markets. The Slovak economy is open and responds very sensitively to global changes. Globalisation brings positive as well as negative impacts on national economies. These impacts are also noticeable in the case of value added wood products. Globally, the furniture trade has grown more quickly than furniture production in the last ten years. The value of the world furniture trade has grown by $65 \%$. On the other hand, domestic sales of furniture are low due to the orientation of the Slovak furniture producers on export, even if at the present time the positive development is reflected in an increasing total sales volume.

Purpose of the article: This paper is focused on the assessment of globalisation impact on value added wood products trade. The aim of the paper is to determine the relationship between the trends of globalisation and furniture trade in Slovakia.

Methods: The development of foreign furniture trade in Slovakia was analysed. In addition, the development of the KOF globalisation index was examined in the period from 2001 to 2017 by applying the linear regression and correlation analysis.

Findings \& Value added: Based on the analysed results, a positive linear relationship between the development of furniture trade in Slovakia and globalisation was observed. The results further show that the impact of globalisation is more significant in the case of export of furniture rather than its import.
\end{abstract}

Keywords: globalisation; furniture trade; KOF globalisation index

JEL Classification: $F 10 ; F 14 ; F 60 ; L 73$

*Corresponding author: michal.dzian@,tuzvo.sk 


\section{Introduction}

Over the past years, the impact of globalisation on the national policy and economy has been extensively researched in many studies. Based on the previous research, we can observe that globalisation brings positive as well as negative impact on national economies. As Beumer [1] stated, current direction of the discussion about globalisation is oriented towards normative desirability of economic globalisation. The sustainability of globalisation is very difficult to measure. Rennen [2] mentions, globalisation is a global complex of phenomenon which is interactive co-evolution of millions of technological, cultural, economic, social and environmental trends.

It is still debated whether globalisation leads to the equality or the inequality $[3,4]$. According to Pleskovic [5], in the last 200 years there has been a downward trend in inequality and the increased globalisation accelerated this decline. On the other hand, Pleninger [6] stated that stronger competition based on globalisation as well as liberalisation of trade caused an increase in inequality.

Globalisation brings the economic growth and specialization of production processes [7]. Zaidi [8] defined globalisation as a process of interaction among governments, corporations and other organizations. He further stated that every person in the world is affected by the impacts of globalisation. Globalisation leads to the expansion of products, technology, information, and jobs across national borders and thus affects economic, political, environmental, health, sociocultural dimensions of every country in the world [9].

The impact of globalisation is also noticeable in the case of forestry and wood processing industry. There are positive as well as negative consequences of globalisation on the mentioned sectors. Suchomel [10] mentions that most important consequences of globalisation are noticeable in the case of countries with the large forest area. In Slovakia, the area of forests reached 1.947 mil. ha in 2018 and the forests cover $41.2 \%$ of the total land. Since 2001, the area of forests has annually increased [11]. Suchomel [10] points out that a significant impact of globalisation on the forestry is reflected in increasing roundwood prices in Slovakia that causes the relocation of the sawmills, pulp and paper industries from the locations where they played an important role for the local development. The Slovak economy is open and very sensitively responds to global changes. The development of the Slovak economy as well as wood processing industry depends on the foreign markets demand [12]. The position of furniture industry in Slovakia has significantly changed over the years. Furniture companies recorded maximum sales in 2016 when, as Haluza [13] stated, they reached 803 million $€$. Currently, we can observe consequences of spreading coronavirus. One of the biggest furniture companies in Slovakia reaches 80\% decrease in its sales [14]. As stated by Yaya [15] globalisation is under threat due to corona virus and we can observe that governments are limiting global trade and flows. On the other hand Zimmermann [16] shows that globalised countries are better protected against the consequences of corona virus spreading and these countries are better equipped to keep fatality rates low.

This study is oriented towards examination of the impact of globalisation on the Slovak furniture industry trade. The development of the KOF globalisation index, export and import of furniture is analysed in the period from 2001 to 2017. The furniture industry represents significant part of the Slovak industry. There are 83 enterprises operating with 20 and more employees with annual turnover over 5 mill. $€$ in 2018 . In the past 4 years, the production of furniture has increased by $17 \%$ and the average number of employees in the furniture industry has increased by $10 \%$ from 2016 to 2018 [17]. In 2017 the value of exported furniture reached 1.48 billion $€$.

Globally, the furniture trade has grown more quickly than furniture production. The furniture trade has grown by $57 \%$ and furniture production has reached 470 bill. USD over the last 10 years. Asia and the Pacific are responsible for almost 54\% of world furniture consumption [18]. 


\section{Material and methods}

The study focuses on the identification of the impact of globalisation on the Slovak furniture industry trade. The development of the KOF Globalisation Index was analysed in the period from 2001 to 2017. The KOF Globalisation Index was applied as an independent variable. Further, the development of furniture exports and imports values were examined and were used as dependent variables. Data were drawn from the UN Comtrade Database [19] and the Swiss Economic Institute database [20].

The KOF Globalisation Index deals with the economic, social and political dimensions of globalization. The KOF Globalisation index includes large panel data from 203 countries and territories over the period of 1970 to 2017. Moreover, the KOF Globalisation Index focuses on measuring globalization at the national level and distinguishes between de facto and de jure globalisation. De jure globalisation is oriented towards the policies and conditions while de facto globalisation index deals with the actual international flows and activities[21].

To analyse the impact of globalisation on the Slovak furniture industry trade linear regression was used. Based on this method we analysed the relationship between the KOF globalisation index and development of exports and imports of furniture in Slovakia. The final general form of model was defined as follows:

$$
F T=f(K O F)
$$

Where $F T$ is furniture trade. The general time series model form used is as follows:

$$
\operatorname{lnFT} T_{t}=\beta_{0}+\beta \ln \mathrm{KOF}_{t}+\varepsilon_{t}
$$

Where $F T_{t}$ is value of furniture export/import, $t$ is year, $\beta_{0}$ is a constant, $K O F_{\mathrm{t}}$ is a vector of explanatory variables and $\varepsilon_{\mathrm{t}}$ is the error term. Last squares estimation method was used to estimate the parameters of model. Variance Inflation Factor and Durbin-Watson test was used to test autocorrelation as well as multicollinearity, respectively. All data were transformed to logarithms in order to be able to interpret directly the estimated model parameters as elasticities.

In addition, the Pearson $r$ correlation was used to examine the relationship between the KOF Globalisation Index and the development of exports and imports of furniture in Slovakia. The following formula was used:

$$
r=\frac{\sum_{i}\left(x_{i}-\bar{x}\right)\left(y_{i}-\bar{y}\right)}{\sqrt{\sum_{i}\left(x_{i}-\bar{x}\right)^{2}} \sqrt{\sum_{i}\left(y_{i}-\bar{y}\right)^{2}}}
$$

The hypothesis $\mathrm{H}_{0}$ assumes no association between the KOF Globalisation Index and the furniture trade in Slovakia. On the other hand, alternative hypothesis $\mathrm{H}_{1}$ assumes that there is an association between the development of globalisation and the Slovak furniture trade. The statistical program SPSS was applied to verified mentioned statistical hypotheses, using the level of significance $\alpha=0.05$. 


\section{Results and Discussions}

The study examines the development of exports and imports of furniture in Slovakia from 2001 to 2017. Figure 1 shows the development of the total value of exports and imports of furniture in EUR. The shape of lines in graph demonstrates that there is an obvious upward trend of the foreign trade of furniture during the examined period. According to Figure 1, the value of import exceeded the value of export by $13 \%$ in 2016 and same trend continued in the year 2017.

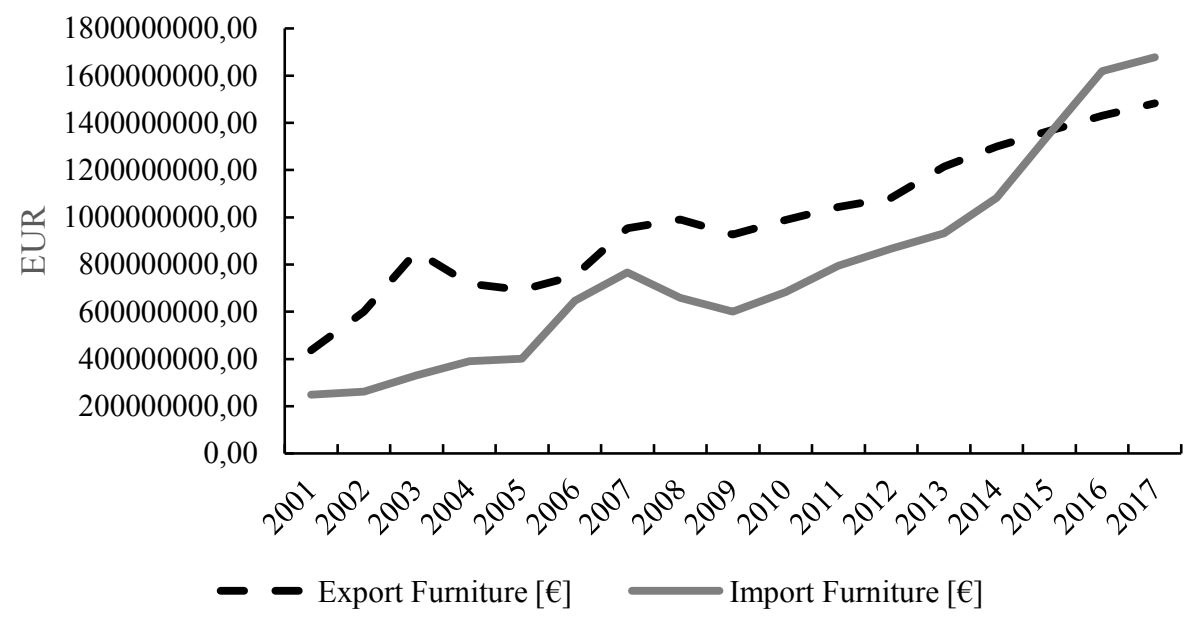

Fig. 1. Development of export and import of furniture in EUR

The development of the KOF Globalisation Index in Slovakia from 2001 to 2017 is depicted in Figure 2. There was a significant increase in the development of KOF Globalisation Index observed in the period from 2001 to 2007. The development of KOF Globalisation Index has been more less stable over the last 10 years.

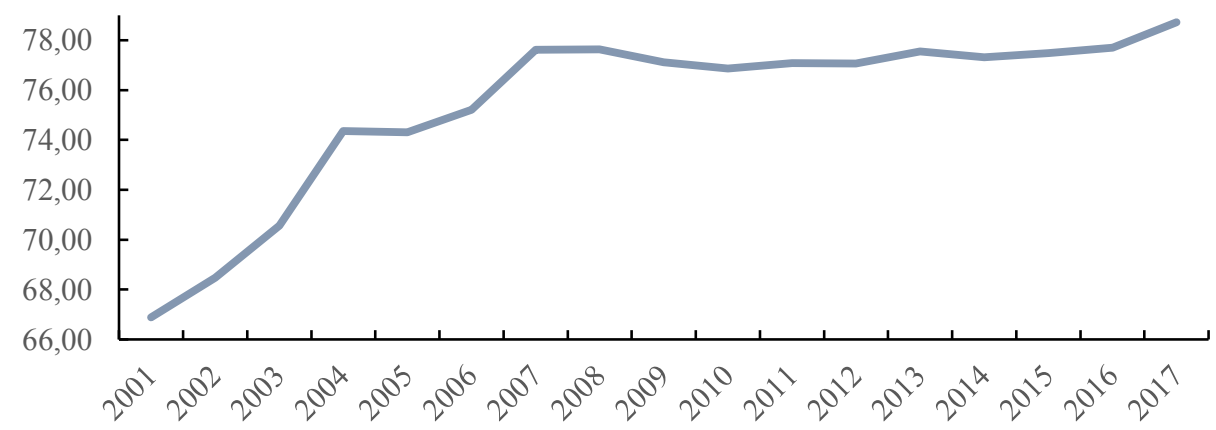

Fig. 2. Development of KOF globalisation index in Slovakia

Following the methodology, linear regression and correlation between the KOF Globalisation Index and the development of export and import of furniture in Slovakia was estimated. Using these methods, basic statistical characteristics of linear regression are displayed in the Table 1. 
Table 1. Statistical characteristics of linear regression

\begin{tabular}{|c|c|c|c|c|c|}
\hline & Constant & Coefficients & $\mathbf{R}^{2}$ & $\mathbf{F}$ & $\mathbf{t}$ \\
\hline $\begin{array}{c}\text { Value of } \\
\text { furniture } \\
\text { exports }\end{array}$ & 6.335 & $0.035 * * *$ & 0.627 & $25.209 * * *$ & $-4.044 * * *$ \\
\hline $\begin{array}{c}\text { Value of } \\
\text { furniture } \\
\text { imports }\end{array}$ & 4.057 & $0.009 * * *$ & 0.551 & $15.688 * * *$ & $-3.499 * * *$ \\
\hline
\end{tabular}

Value represent data in EUR; $* * *=\alpha<0.001$

The results of correlation between KOF and the development of furniture foreign trade are shows in Table 2.

Table 2. Statistical characteristics of Pearson Correlation

\begin{tabular}{|c|c|}
\hline & Pearson Correlation Coefficient \\
\hline Value of furniture export & $0.792^{* * *}$ \\
\hline Value of furniture import & $0.715^{* * *}$ \\
\hline
\end{tabular}

Value represent data in EUR; $* * *=\alpha<0.001 \%$

The results of statistical hypotheses show a statistically significant linear relationship between the KOF Globalisation Index and development of the furniture trade in Slovakia. Based on statistical characteristics of linear regression we can observe that the export represents the most affected part of the furniture trade. However, the development of both, exports and imports of furniture was strongly affected by globalisation. In both cases, exports and imports observed positive dependence. In other words, an increase in the KOF Globalisation Index causes also a growth in the furniture trade. Models of export and import of furniture contain parameters of models which are direct elasticities. An increase of the KOF Globalisation Index by $1 \%$ causes an increase in export of furniture by $0.035 \%$ and import by $0.009 \%$. As mentioned above, the development of export and import values of furniture in Slovakia shows an upward trend. There are many factors affecting the trade of furniture in Slovakia. As Kaputa et al. [22] stated, for wood processing companies there are many barriers to enter foreign markets. The most significant barrier for the Slovak exporters of wood products is foreign competition. Slovak furniture producers are mostly oriented on export. Considering rich capacity of wood biomass in Slovakia, the country could become an important player on the Europe furniture market. Volume of sales is increasing, however, domestic sales are noticeably low [23]. The process of globalisation may help to increase the company's productivity and possibility to expand into foreign international markets [24].

The impact of globalisation on the furniture trade in Slovakia is disputable. On one hand, globalisation brings positive impact on economic development in Slovakia. As Pelegrinova et al. [24] stated, globalisation causes an increase of the GDP in Slovakia and brings positive effect on foreign direct investments. On the other hand, there are many consequences of globalisation with negative impact on wood processing industry complex. The major issue of Slovak forest industry is relatively high export of roundwood without any added value [25]. There are several reasons for this, however, the most important is represented by missing production capacities for processing high value assortment of roundwood. 


\section{Conclusion}

This study analysed the impact of globalisation on value-added wood products trade. We focused on the foreign trade of furniture industry products in Slovakia and examined the development of globalisation from 2001 to 2017. Consequently, the furniture trade in Slovakia was evaluated on the basis of development of export and import values. Our findings show a significant relationship between the furniture trade and the development of globalisation in Slovakia. Based on the results of the study, it can be stated that globalisation has a significant impact on the furniture trade in Slovakia.

The authors are grateful for the support of the Scientific Grant Agency of the Ministry of Education, Science, Research, and Sport of the Slovak Republic, Grant No. 1/0666/19 Determination of the Development of a Wood-based Bioeconomy

\section{References}

1. Beumer, C., Figge, L., Elliott, J. (2018). The sustainability of globalisation: Including the 'social robustness criterion.' Journal of Cleaner Production, 179, 704-715.

2. Rennen, W., Martens, P. (2003). The Globalisation Timeline. Integrated Assessment, 4(3), 137-144.

3. Heimberger, P. (2020). Does economic globalisation affect income inequality? A metaanalysis. World Economy, 43(11), 2960-2982.

4. de Zwart, P. (2020). Globalisation, Inequality and Institutions in West Sumatra and West Java, 1800-1940. Journal of Contemporary Asia, n/a(n/a).

5. Pleskovic, B., Stern, N. (2002). Annual World Bank Conference on Development Economics. Washington: Oxford University Press, New York.

6. Pleninger, R., Sturm, J.-E. (2020). The effects of economic globalisation and ethnic fractionalisation on redistribution. World Development, 130, 104945.

7. Šupín, M. (2014). The Impact of the Global Recession on Wood Processing Industry and Wood Products Trade and the Road to Recovery. In POSITION AND ROLE OF THE FOREST BASED SECTOR IN THE GREEN ECONOMY (pp. 159-164). Zvolen, Slovakia: WoodEMA, i.a.

8. Zaidi, S. A. H., Zafar, M. W., Shahbaz, M., Hou, F. (2019). Dynamic linkages between globalization, financial development and carbon emissions: Evidence from Asia Pacific Economic Cooperation countries. Journal of Cleaner Production, 228, 533-543.

9. Intriligator, M. D. (2009). Globalisation of the world economy: Potential benefits and costs and a net assessment. The Law and Economics of Globalisation: New Challenges for a World in Flux, (33), 299-314. Glos : Edward Elgar Publishing.

10. Suchomel, J., Gejdoš, M., Ambrušová, L., Šulek, R. (2012). Analysis of price changes of selected roundwood assortments in some Central Europe countries. Journal of Forest Science, 58(11), 483-491.

11. National Forest Centre. (2019). Report on the Forest Sector of the Slovak Republic 2018 - GREEN REPORT. Zvolen: Ministry of Agriculture of the Slovak Republic, National Forest Centre.

12. Loučanová, E., Olšiaková, M., Dzian, M. (2018). Suitability of innovative marketing communication forms in the furniture industry. Acta Facultatis Xylologiae, 60(1), 159171. 
13. Haluza, I. (2016). Nábytkári sa kúpu v rekordných tržbách. TREND. Retrieved from: https://www.trend.sk/trend-archiv/nabytkari-kupu-rekordnych-trzbach

14. Rácz, Z. (2020). Fil’akovský výrobca nábytku: Na 60 percentách mzdy vydržíme najviac tri mesiace. TREND. Retrieved from: https://www.trend.sk/financie/filakovsky-vyrobcanabytku-60-percentach-mzdy-vydrzime-najviac-tri-mesiace

15. Yaya, S., Yaya, S., Otu, A., Otu, A., Labonté, R. (2020). Globalisation in the time of COVID-19: Repositioning Africa to meet the immediate and remote challenges. Globalization and Health, 16(1), 51.

16. Zimmermann, K. F., Karabulut, G., Bilgin, M. H., Doker, A. C. (2020). Inter-country distancing, globalisation and the coronavirus pandemic. World Economy, 43(6), 14841498.

17. ŠÚSR-Štatistický úrad Slovenskej Republiky. (2019). Yearbook of Industry of the SR 2019. Science and Public Policy. Bratislava: Štatistický úrad Slovenskej republiky.

18. UNECE. (2019). Forest Products Annual Market Review 2018-2019. Geneva, Switzerland: United Nations.

19. UN Comtrade Database. (n.d.). Retrieved from: https://comtrade.un.org/

20. Swiss Economic Institute. (2019). KOF Globalisation Index. Retrieved from: https://kof.ethz.ch/en/forecasts-and-indicators/indicators/kof-globalisation-index.html

21. Gygli, S., Haelg, F., Potrafke, N., Sturm, J. E. (2019). The KOF Globalisation Index revisited. Review of International Organizations, 14(3), 543-574.

22. Kaputa, V., Paluš, H., Vlosky, R. (2016). Barriers for wood processing companies to enter foreign markets: a case study in Slovakia. European Journal of Wood and Wood Products, 74(1), 109-122.

23. Slovak Investment and Trade Development Agency. (2010). Forests and the WoodProcessing Industry. SARIO. Retrieved http://www.sario.sk/sites/default/files/content/files/woodprocessing_sk.pdf

24. Pelegrinová, L., Lačný, M. (2013). Analýza vplyvu globalizačných procesov na ekonomiky vyspelých krajín. Annales Scientia Politica, 2(2), 27-35.

25. Ministry of Agriculture and Rural Development of the Slovak Republic, National Forest Centre. (2018). Slovak Market Report 2018 Statement submitted to the 76th session of the ECE Committee on Forests and Forest Industry. Zvolen. Retrieved from: http:/www.unece.org/fileadmin/DAM/timber/country-info/statements/slovakia2018.pdf 